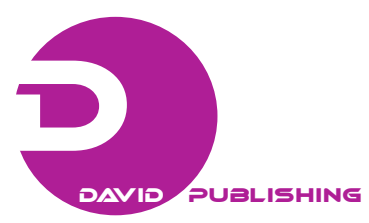

\title{
Levels of Radon Activity Concentration in Thermal Waters of Bosnia and Herzegovina
}

\author{
Amela Kasic, Ema Hankic, Amira Kasumovic and Feriz Adrovic \\ University of Tuzla, Faculty of Science, 75000 Tuzla, Bosnia and Herzegovina
}

Received: March 28, 2013 / Accepted: April 21, 2013 / Published: August 25, 2013.

\begin{abstract}
Radon is a natural radioactive gas which is colorless, tasteless and odorless. Using the water which contains bigger quantities of radioactive radon might cause cancer or other health problems. This paper presents the results of radon activity concentration in spas in area of Bosnia and Herzegovina. The obtained results of radon activity concentration in thermal test samples range within the interval of $(254-4,715) \mathrm{mBq} / \mathrm{L}$, which does not exceed recommended Enviromental Protection Agency (EPA) value of $11.1 \mathrm{~Bq} / \mathrm{L}$ in drinking water. The measurements of radon activity concentration are done with AlphaGUARD and AquaKIT equipment (Genitron Instruments-Frankfurt).
\end{abstract}

Key words: Radon activity concentration, thermal water, Bosnia and Herzegovina.

\section{Introduction}

Radon is a colorless, odorless and tasteless natural gas. It is chemically inert, meaning that it does not have the ability to build compounds in nature. Radon belongs to the class of heavy gases and it stays on different surfaces creating the radioactive remains of radioactive isotopes of polonium, lead, bismuth.

Genetic connection with uranium makes radon useful in searching for uranium ore, while its chemical inertness makes it useful tracer of geophysical processes that lead to the movement of gas through the earth (prediction of earthquakes and volcanic eruptions). On the other hand, the radioactivity makes radon harmful to health. Normally, radon dissolves in water, body and blood. The radon solubility in fat is hundred times higher than in blood, and the solubility in the blood is four times higher than in water [1]. This feature is of great impact on the curative effects of radon. Radon is considerably more soluble in water than the lighter noble gases (which is worrying) about fifteen times more than helium and neon. The

Corresponding author: Feriz Adrovic, full professor, research fields: radon, gamma spectrometry, radiation protection, E-mail: adrovicferiz@yahoo.com. radioactive gas radon is soluble in water, but when water is boiling, radon is going out of it. Environmental Protection Agency has proposed a maximum contamination level (MCL) for radon in drinking water which is $11.1 \mathrm{~Bq} / \mathrm{L}$ [2].

On the other hand, exposure to certain radon concentrations can have a therapeutic effect. The radon treatment is one of the oldest therapy that people have used. In Europe radon therapy is present in many modern rehabilitation centers. Inhalation is based on the inhalation of radon gas or of radon descendant particles dispersed in the air. There are famous radon spas in Germany, Austria, France, Czech Republic, Italy, Japan, New Zealand, etc.. Radon therapy is used in the treatment of many diseases. It is known that radon reduces pain as well as it boosts general immunity. It is used for acute and chronic rheumatism, it improves mobility and circulation, and it is beneficial to some skin, endocrine, respiratory and allergic diseases.

In the process of creation, existence, restoring and highlighting of mineral waters, the important role is attributed to origin of the rocks, their hydrogeological structure and mineral composition, as well as to 
geochemical and microbiological conditions and processes where the waters are creating. By penetrating through certain types of rocks or other terrains, waters dissolve them and take them with themselves, in which way spring waters get certain characteristic features [3].

Mineral waters are those that have more than one gram of soluble mineral matters in one liter, which gives them a specific taste and smell. Thermal waters occur more often in nature, since they are coming from the greater depths, and on its way they are heated up from the warm rocks and they dissolve minerals [4]. Temperatures of thermal waters range from 15 to over 100 degrees.

Spas are settlements near thermal wells whose water is used for the medical treatment and tourism purposes. Spas are usually used for tourism, recreation, rehabilitation, medical treatment and the treatment by drinking mineral water. Among the famous spas of Bosnia and Herzegovina are: Aquaterm-Olovo, Dvorovi-Bijeljina, Gata-Bihać, Guber-Srebrenica, Ilidža-Gradačac, Kulaši-Prnjavor, Laktaši-Banja Luka, Reumal-Fojnica, Slatina-Banja Luka, Vrućica-Teslić.

\section{Material and Methods}

Determining of radon concentration in a water sample is based on the determination of radon concentration in the air. Detection and measurement of radon concentration activity can be done directly, by measuring the radon itself, or indirectly, through his descendants. In this study AlphaGuard PQ 2000 PRO is used together with AlphaPump and AquaKit equipment in order to determine radon concentration activity during radon exhalation (Fig. 1).

The main condition for correctness and exactness of measurement of radon activity concentration in water is appropriate sampling. In particular the radon losses on the way between sampling and the measurement have to be minimized. During the writing of this study the method of direct transfer of samples was used together with plastic injections of $100 \mathrm{~mL}$ that can hold

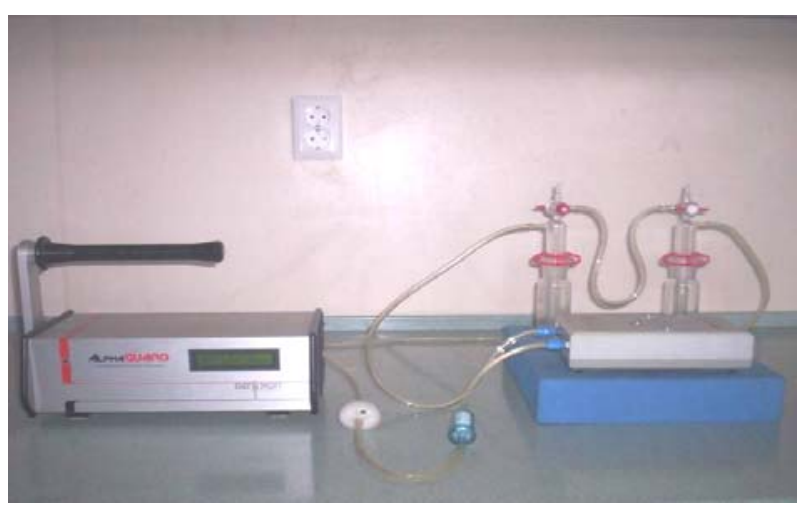

Fig. 1 Measuring equipment for determination of radon activity concentration in water.

$100 \mathrm{~mL}$ of liquid measurement. Then, the sample is being injected directly from the injection into the upper opening of degased container. The experimental part was carried out in the Laboratory for detection, dosimetry and radiation protection (LDDZZ), at Faculty of Sciences in Tuzla. It was also taken in consideration that the time from sampling to the point of measurement was as short as possible. During the sample taking process it was taken care of how to avoid stirring up of the water, which would lead to the radon departure from the sample, and that the measurement should be done in as short period of time as possible.

AlphaGUARD is a device of light weight and it has a high capacity of data storage. Besides determining of radon concentration in the air, AlphaGuard measures and records the ambient temperature, relative humidity and atmospheric pressure by using integrated sensors. Measuring range of this device for radon activity concentration is from $2-2 \times 10^{6} \mathrm{~Bq} / \mathrm{m}^{3}$, while the temperature range is from -10 to $50{ }^{\circ} \mathrm{C}$. The main part of the device, AlphaGUARD PQ2000 PRO [5], is the ionization chamber of the active volume of $0.56 \mathrm{dm}^{3}$. The device can operate in two operating modes: with diffusion and with pump.

AquaKIT is a set of needs of mainly glass equipment for direct measurement of radon gas in the water, whose unreliability of the system is negligible. This set is used for all waters, waste waters and highly salted waters as well. Measurements of radon in water 
samples by using AquaKIT [6] are precise and correct. Glass vessels of AquaKIT measuring equipment provide hermetically enclosed space of ejected radon from the water sample, as well as the quick exchange of samples, which prevents incorrect measurements as a result of the leak. In a closed circulating gas radon is ejected from the water sample with the help of AlphaPUMP. With the AlphaGUARD PQ2000PRO, whose ionization chamber is also part of the gas cycle, the radon concentration in the system is determined and stored in its memory.

In Fig. 2, there is a map of the investigated sites in Bosnia and Herzegovina. Thermomineral water was sampled from Ilidža Spa, Slatina Spa, Laktaši Spa, Vrućica Spa, Reumal Spa, Dvorovi Spa, Aquaterm Spa, Kulaši Spa, Gata Spa, Termalna Rivijera Ilidža, Guber Spa and Terme. As in the previous period Guber Spa from Srebrenica was devestated, water inside of it is sampled from wells: Crni Guber, Mali Guber, Voda Ljepotica and Očna Voda. Samples were taken from Slana Voda, which is used in our famous Pannonian lakes. When sampling from Termalna Rivijera Ilidža, Sarajevo, thermal water was sampled, which is used for heating up the famous pools at these sites.

For the determination of radon concentration in water sample the following equation was used:

$$
C_{\text {water }}=\frac{C_{\text {air }} \cdot\left(\frac{V_{\text {System }}-V_{\text {Sample }}}{V_{\text {Sample }}}+k\right)-C_{0}}{1000}
$$

$C_{\text {water }}$ is radon concentration in water sample, $\mathrm{Bq} / \mathrm{L}$; $C_{\text {air }}$ is radon concentration in $\mathrm{Bq} / \mathrm{m}^{3}$ after expelling of the radon, indicated by Alpha Guard; $C_{0}$ is radon concentration in the measuring equipment before sampling, $\mathrm{Bq} / \mathrm{m}^{3} ; V_{\text {system }}$ is interior volume of the measurement equipment, $1,122 \mathrm{~mL} ; V_{\text {sample }}$ is volume of the water sample, $\mathrm{mL} ; \mathrm{k}$ is radon diffusion coefficient

Diffusion coefficient of radon can be temperature dependant, but the influence of the radon diffusion coefficient is only low in the temperature range

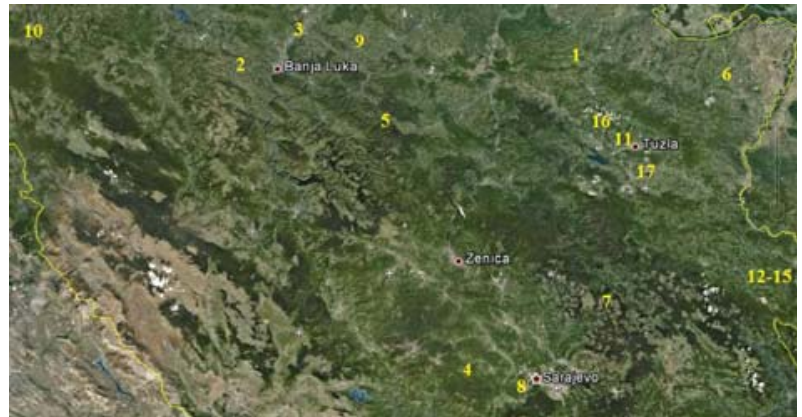

Fig. 2 A map of the investigation locations in Bosnia and Herzegovina.

between $10{ }^{\circ} \mathrm{C}$ and $30{ }^{\circ} \mathrm{C}$. Depending on the temperature diffusion coefficient of radon was calculated from the following relation:

$$
k=0.106+0.405 e^{-0.052 t}
$$

where, $k$ is diffusion coefficient of radon; $t$ is temperature of the water.

During the calculating of radon activity concentration it was taken care of the time between water sampling and measuring. Radon activity concentration in the water sample with the time correction was introduced using the equation (3).

$$
C_{0}=\frac{C(t)}{e^{\lambda t}}
$$

$C_{0}$ is calculated initial concentration of radon activity in the water, $\mathrm{Bq} / \mathrm{L} ; C(t)$ is radon activity concentration in the water sample mesured according to Eq. (1).

Based on the results of the measurements radon activity concentration in the water sample was calculated annual effective ingestion dose of radon, for patients during treatment in spas, using the Eq. (4)

$$
H=C \cdot D \cdot G \cdot T
$$

$H$ is annual effective ingestion dose for radon, $\mathrm{Sv} / \mathrm{y}$; $C$ is radon activity concentration in the water sample, $\mathrm{mBq} / \mathrm{L} ; D$ is ingesting dose conversion factor of radon, $3.5 \mathrm{nSv} / \mathrm{Bq}$; $G$ is the water consumption per day; $T$ is duration of consumption, here it is four weeks.

When estimating the dose related to the radon content of the investigation thermal waters, it has to be understood, that these waters do not constitute a part of continuous drinking water supply, but are applied as medical waters for well defined periods and 
given in amounts. Therapeutic application usually takes several weeks and includes daily doses of 0.2-2 1 . The estimated dose in a drinking cure was calculated as based on the recommendations of ICRP on condition that during a four week drinking cure the patient consumes $1 \mathrm{~L} / \mathrm{d}[7]$.

\section{Results and Discussion}

The research results obtained in this study are the first measurements of radon activity concentration in thermal waters in Bosnia and Herzegovina. The measurements were performed in the famous spa centers: Aquaterm-Olovo, Dvorovi-Bijeljina, Gata-Bihac, Guber-Srebrenica (Mali Guber, Veliki Guber, Očna Voda, Voda Ljepotica), Ilidža-Gradačac, Kulaši-Prnjavor, Laktaši-Banja Luka, Reumal-Fojnica, Slatina-Banja Luka, Vrućica-Teslić. Sampled thermal waters were taken from Terme in Gracanica, thermal pool in Slavinovići and Slana Voda from Tuzla.

The results of measurements of radon activity concentration in thermal waters in the research areas are presented in Table 1 and in the Fig. 3. According to the research results in Table 1 and in Fig. 3, it can be concluded that the radon diffusion coefficient decreases with the temperature increase, and that it increases with the temperature drop. The results in Table 1 and in the Fig. 3, show that the radon activity concentration on the researched locations is in the range of $(254-4,715) \mathrm{mBq} / \mathrm{L}$. The highest value was recorded at the site of Slatina Spa $(4,715 \pm 653)$ $\mathrm{mBq} / \mathrm{L}$. By its physico-chemical properties the thermal water of Slatina Spa is mineral water $(2,700$ $\mathrm{mg} / \mathrm{L}), \mathrm{Ca}, \mathrm{Mg}$, hydrocarbonate, sulfate, coal acidic, hyperthermic $\left(40-42^{\circ} \mathrm{C}\right) . \mathrm{pH}$ value of the water is 7.4 (alkaline). The water temperature at the well is $42^{\circ}$ and by the natural fall the water leads to four indoor

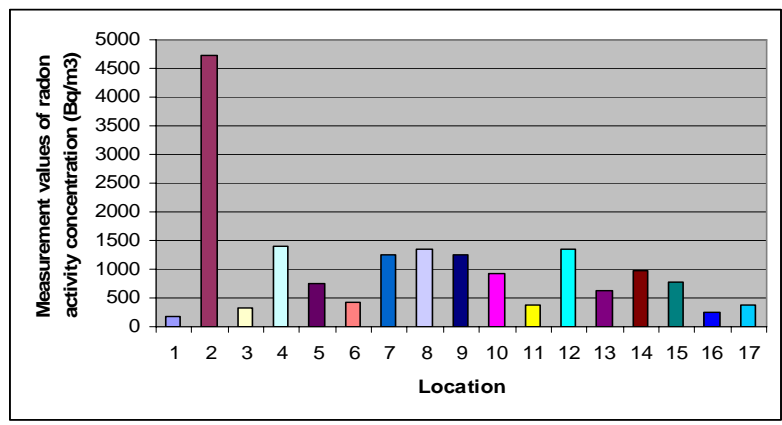

Fig. 3 Radon activity concentration in thermal water sample of Bosnia and Herzegovina.

Table 1 Valuesof radon activity concentration and diffusion coefficient of radon in thermal water samples of Bosnia and Herzegovina.

\begin{tabular}{|c|c|c|c|c|c|c|c|}
\hline $\begin{array}{l}\text { Sample } \\
\text { number }\end{array}$ & Location & Municipality & $\begin{array}{l}\text { Temperature } \\
\left({ }^{\circ} \mathrm{C}\right)\end{array}$ & $\begin{array}{l}\text { Diffusion } \\
\text { coefficient }\end{array}$ & $\mathrm{C}_{\mathrm{W}}(\mathrm{mBq} / \mathrm{L})$ & $t(\mathrm{~h})$ & $\begin{array}{l}\mathrm{C}_{\mathrm{Wo}} \\
(\mathrm{mBq} / \mathrm{L})\end{array}$ \\
\hline 1 & Ilidža Spa & Gradačac & 28.5 & 0.20 & $168 \pm 68$ & 3 & $172 \pm 69$ \\
\hline 2 & Slatina Spa & Banja Luka & 41 & 0.15 & $4,448 \pm 616$ & 8 & $4,715 \pm 653$ \\
\hline 3 & Laktaši Spa & Laktaši & 31 & 0.19 & $265 \pm 107$ & 24 & $317 \pm 128$ \\
\hline 4 & Reumal Spa & Fojnica & 30.5 & 0.19 & $1,313 \pm 297$ & 8 & $1,392 \pm 315$ \\
\hline 5 & Vrućica Spa & Teslić & 37.5 & 0.16 & $711 \pm 273$ & 4 & $739 \pm 283$ \\
\hline 6 & Dvorovi Spa & Bijeljina & 57 & 0.13 & $403 \pm 118$ & 6 & $423 \pm 124$ \\
\hline 7 & Aquaterm Spa & Olovo & 34 & 0.18 & $731 \pm 214$ & 72 & $1,260 \pm 368$ \\
\hline 8 & Termalna Rivijera Ilidža & Sarajevo & 58 & 0.12 & $658 \pm 201$ & 96 & $1,356 \pm 414$ \\
\hline 9 & Kulaši Spa & Prnjavor & 27 & 0.20 & $729 \pm 219$ & 72 & $1,256 \pm 376$ \\
\hline 10 & Gata Spa & Bihać & 32 & 0.18 & $378 \pm 131$ & 120 & $936 \pm 323$ \\
\hline 11 & Slana Voda & Tuzla & 24 & 0.22 & $362 \pm 119$ & 2 & $367 \pm 120$ \\
\hline 12 & Crni Guber & Srebrenica & 13 & 0.31 & $1,324 \pm 331$ & 3 & $1,354 \pm 338$ \\
\hline 13 & Mali Guber & Srebrnica & 13 & 0.31 & $587 \pm 173$ & 6 & $614 \pm 182$ \\
\hline 14 & Voda Ljepotica & Srebrenica & 13 & 0.31 & $912 \pm 246$ & 8 & $968 \pm 266$ \\
\hline 15 & Očna Voda & Srebrenica & 13 & 0.31 & $711 \pm 203$ & 10 & $767 \pm 219$ \\
\hline 16 & Terme & Gračanica & 35 & 0.17 & $249 \pm 87.5$ & 3 & $254 \pm 89$ \\
\hline 17 & $\begin{array}{l}\text { Thermal pool in } \\
\text { Slavinovići }\end{array}$ & Tuzla & 33 & 0.18 & $350 \pm 118$ & 5 & $364 \pm 124$ \\
\hline
\end{tabular}


Table 2 Annual effective dose for radon received by individuals during a four week thermal water drinking cure.

\begin{tabular}{lllr}
\hline Sample number & Location & Municipality & $\begin{array}{l}\text { Annual effective ingestion dose } \\
(\mu \mathrm{Sv}) 4 \text { weeks }\end{array}$ \\
\hline 1 & Ilidža Spa & Gradačac & $0.017 \pm 0.007$ \\
2 & Slatina Spa & Banja Luka & $0.46 \pm 0.064$ \\
3 & Laktaši Spa & Laktaši & $0.032 \pm 0.012$ \\
4 & Reumal Spa & Fojnica & $0.14 \pm 0.028$ \\
5 & Vrućica Spa & Teslić & $0.072 \pm 0.028$ \\
6 & Dvorovi Spa & Bijeljina & $0.041 \pm 0.012$ \\
7 & Aquaterm Spa & Olovo & $0.124 \pm 0.036$ \\
8 & Termalna Rivijera Ilidža & Sarajevo & $0.132 \pm 0.04$ \\
9 & Kulaši Spa & Prnnjavor & $0.12 \pm 0.036$ \\
10 & Gata Spa & Bihać & $0.092 \pm 0.032$ \\
11 & Slana Voda & Tuzla & $0.036 \pm 0.012$ \\
12 & Crni Guber & Srebrenica & $0.132 \pm 0.032$ \\
13 & Mali Guber & Srebrnica & $0.060 \pm 0.012$ \\
14 & Voda Ljepotica & Srebrenica & $0.094 \pm 0.026$ \\
15 & Očna Voda & Srebrenica & $0.075 \pm 0.0216$ \\
16 & Terme & Gračanica & $0.025 \pm 0.008$ \\
17 & Thermal pool in Slavinovići & Tuzla & $0.036 \pm 0.012$ \\
\hline
\end{tabular}

Table 3 Gamma dose rate on explored locations in Bosnia and Herzegovina

\begin{tabular}{|c|c|c|c|c|c|c|}
\hline \multirow{2}{*}{$\begin{array}{l}\text { Sample } \\
\text { number }\end{array}$} & \multirow{2}{*}{ Location } & \multirow{2}{*}{ Municipality } & \multirow{2}{*}{$\begin{array}{l}\text { Place of } \\
\text { measurements }\end{array}$} & \multicolumn{3}{|c|}{ Gamma dose rate $(\mu \mathrm{Sv} / \mathrm{h})$} \\
\hline & & & & $\max$ & mean & $\min$ \\
\hline 1 & Ilidža Spa & Gradačac & bathtubs & 0.28 & 0.18 & 0.07 \\
\hline 2 & Slatınaspa & Banja Luka & bathtubs & 0.39 & 0.2 & 0.06 \\
\hline 3 & Slatına spa & Banja Luka & peloid & 0.19 & 0.15 & 0.1 \\
\hline 4 & $\begin{array}{l}\text { Laktasi spa } \\
\text { Reumal Spa }\end{array}$ & Banja Luka & swimming pool & 0.26 & 0.14 & 0.04 \\
\hline 5 & Keumal spa & Fojnica & bathtubs & 0.2 & 0.15 & 0.05 \\
\hline 6 & Reumal Spa & Fojnica & swimming pool & 0.19 & 0.12 & 0.04 \\
\hline 7 & Vrucica Spa & Teslić & bathtubs & 0.22 & 0.13 & 0.06 \\
\hline 8 & Dvorov1 Spa & Bijeljina & bathtubs & 0.22 & 0.12 & 0.03 \\
\hline 9 & Dvorovi Spa & Bijeljina & showers & 0.26 & 0.17 & 0.09 \\
\hline 10 & Dvorov1 Spa & Bijeljina & fountain & 0.22 & 0.14 & 0.04 \\
\hline 11 & Aquaterm Spa & Olovo & bathtubs & 0.13 & 0.09 & 0.04 \\
\hline 12 & Aquaterm Spa & Olovo & swimming pool & 0.22 & 0.11 & 0.02 \\
\hline 13 & Kulas1 spa & Prnjavor & fountain & 0.21 & 0.13 & 0.03 \\
\hline 14 & Mall uuber & Srebrenica & spring & 0.27 & 0.21 & 0.15 \\
\hline 15 & Oćna Voda & Srebrenica & spring & 0.29 & 0.20 & 0.13 \\
\hline 16 & voda Ljepotica & Srebrenica & spring & 0.34 & 0.22 & 0.13 \\
\hline 17 & Thermel nool in & Gračanica & swimming pool & 0.24 & 0.12 & 0.02 \\
\hline 18 & $\begin{array}{l}\text { Thermal pool in } \\
\text { Slavinovići }\end{array}$ & Tuzla & showers & 0.23 & 0.12 & 0.02 \\
\hline
\end{tabular}

pools with installed underwater massage and sixteen bathtubs. According to the results, the minimum value of the radon activity concentration in the water sample, is $(254 \pm 89) \mathrm{mBq} / \mathrm{L}$, at the Terme, Gračanica.

The results in Table 2, show that the annual effective ingestion dose for radon on the researched locations is in the range of $0.13-0.46 \mu \mathrm{Sv} / \mathrm{y}$. The higest value was recorded at the site of Slatina Spa $0.46 \mu \mathrm{Sv} / \mathrm{y}$, during a four week thermal water drinking cure. The minimum value of effective dose for radon is $0.017 \mu \mathrm{Sv} / \mathrm{y}$, at the Ilidža Spa, Gradačac.

On the researched places dose rate of gamma 
radiation was measured, too. Research results show that the maximum value of the dose rate of gamma radiation is at the site of Slatina Spa, with a maximum value of $0.39 \mu \mathrm{Sv} / \mathrm{h}$, in the therapeutic blocks (Table 3). The minimum therapeutic dose is at the site of the Aquaterm Spa, with the value of $0.13 \mu \mathrm{Sv} / \mathrm{h}$.

\section{Conclusions}

The research results do not show increased radon activity concentration and gamma dose rate in thermal waters in investigated spas of Bosnia and Herzegovina. Radon activity concentrations in thermal waters of Bosnia and Herzegovina are below the maximum level of water contamination by radioactive gas radon of $11.1 \mathrm{~Bq} / \mathrm{L}$. The highest value radon activity concentration and gamma dose rate were observed at the location of Slatina Spa, but it is also under the maximum level of contamination. Generally it can be imposed that the radon activity concentrations in water at most of investigated locations are lower than the world average.

The estimated annual effective doses for radon received by individuals undergoing drinking therapy over a period a four weeks at investigated spas in Bosnia and Herzegovina, are below the recommended value of $0.002 \mathrm{mSv} / \mathrm{y}$.

The results of these investigations, other than medical aspect, are in the function of various applications, such as prospection of minerals for geothermal researches, earthquakes prediction and volcanic eruptions, etc..

The obtained results will be the initial database for mapping and forecasting of geogenetic potential of radon in air, water and soil, thus being a valuable contribution to the map of natural radioactivity of Bosnia and Herzegovina.

\section{References}

[1] F. Adrović, A. Dedić, Radon as therapeutic or cause of cancer, Seminary for theacers and professors of physics, in Proceedings of Lectures, Physical Society in Bosnia and Herzegovina, Fojnica, 2007, pp. 104-112.

[2] Committee on Risk Assessment of Exposure to Radon in Drinking Water, Risk assessment of radon in drinking water, National Academy Press, Washington D. C., 1999.

[3] UNSCEAR, Sources and effects of ionising radiation, Report of the United Nations Scientific Committee on the Effects of Atomic Radiation to the General Assembly, United Nations, New York, USA, 2000.

[4] World Health Organization (WHO): Guidelines for Drinking-Water Quality, 3 rd edition, 2004, pp. 197-210.

[5] AlphaGuard PQ 2000/MC50 Multiparametar Radon Monitor, Characterisation of its physical properties under normal climatic and severe enviromental conditions, User Manual, Genitron Instruments Germany, 1998, pp. 2-6.

[6] AquaKIT, Accessory for radon in water measurement in combination with the radon monitor AlphaGUARD, User Manual, Genitron Instruments Germany, 1997, pp. 5-8.

[7] International Commission of Radiological Protection (ICRP), Limits for Intakes of Radionuclides by Workers, ICRP Publication 30 (Supplement to Part 1), Annals of ICRP 2 (3-4), Pergamon Press, Oxford, England, 1979. 